\title{
Hubungan Aktivitas Fisik terhadap Tinggi Badan pada Mahasiswa Fakultas Kedokteran Umum Universitas YARSI yang Berumur Kurang dari atau Sama dengan 20 Tahun
}

\section{The Relationship of Physical Activities to Height of Students at the Faculty of Medicine in YARSI University Aged Less Than or Same with 20 Years Old}

\author{
Adinda Savitri ${ }^{1}$, Yenni Zulhamidah ${ }^{2 *}$, Etty Widayanti ${ }^{3}$ \\ ${ }^{1}$ Student Faculty of Medicine, YARSI University, Jakarta \\ ${ }^{2}$ Department of Anatomy, Faculty of Medicine, YARSI University, Jakarta \\ ${ }^{3}$ Department of Biology, Faculty of Medicine, YARSI University, Jakarta \\ Jalan Letjen. Suprapto, Cempaka Putih, Jakarta 10510 \\ Telephone (021) 4206674, 4206675, 4206676 \\ *Corresponding author: yz7313@gmail.com
}

\begin{abstract}
Abstrak
Latar Belakang: Penelitian sebelumnya telah menemukan hubungan antara ukuran tinggi badan pendek dengan tingkat pendidikan dan produktivitas manusia di masa depan. Beberapa penelitian telah menemukan bahwa aktivitas fisik berkorelasi dengan optimalisasi pertumbuhan massa mineral tulang yang dicapai pada awal usia 20 tahun, selanjutnya akan mempengaruhi pertumbuhan tinggi badan. Tujuan dari penelitian ini adalah untuk membuktikan hipotesis tentang hubungan antara aktivitas fisik dengan tinggi pada remaja usia lanjut. Metode: Desain penelitian yang digunakan dalam penelitian ini adalah kuantitatif korelasional dengan pendekatan Cross Sectional. Populasi sampel yang digunakan adalah mahasiswa kedokteran tahun pertama dan kedua Universitas YARSI yang berusia $\leq 20$ tahun. Penentuan intensitas aktivitas fisik harian menggunakan kuesioner dan Global Physical Activity Questionnaire (GPAQ). Tinggi diperoleh dengan pengukuran tinggi badan responden secara langsung dan dikategorikan ke dalam tiga kelompok berdasarkan kurva CDC 2000. Data dianalisis dengan uji statistik Pearson Chi Square. Hasil: Analisis bivariat menunjukkan bahwa tidak ada hubungan antara aktivitas fisik pada remaja dengan tinggi badan dengan nilai $P(P=0,992<5 \%)$, tetapi ditemukan hubungan antara aktivitas fisik selama periode prapubertas dengan tinggi badan dengan nilai $P(P=0,045<5 \%)$. Simpulan: Aktivitas fisik yang dilakukan selama masa remaja tidak memiliki hubungan dengan tinggi badan, tetapi aktivitas fisik yang dilakukan selama periode prapubertas memiliki hubungan terhadap tinggi badan.
\end{abstract}

Kata kunci: Aktivitas Fisik; Tinggi Badan; Mahasiswa

\section{Abstract}

Beckground: Previous studies have found a relationship between short height with future level education and human productivity. Some studies have found that physical activity correlates with the optimization of bone mineral mass growth achieved at the beginning of the age of 20 years, then it 
will affect the size of the height. The aim of this study was to prove the hypothesis about the relationship between physical activity to height in adolescence. Method: The research design used in this study is quantitative correlational with Cross Sectional approached. The sample population used was the first and second year medical students of YARSI University aged $\leq 20$ years. Determination of the intensity of daily physical activity using questionnaires and Global Physical Activity Questionnaire (GPAQ). Height is obtained by measuring the respondent's height directly and categorized into three groups based on the CDC 2000 curve. Height is obtained by measuring the respondent's height directly and categorized into three groups based on the CDC 2000 curve. Data were analyzed by Pearson Chi Square statistical tests. Results: Bivariate analysis showed that there are no relationship between physical activity in adolescence to body height with $P$ value $(P=0.992<5 \%)$, but it found a relationship between physical activity during prepubertal periods to body height with $P$ value $(P=$ $0.045<5 \%)$. Conclusion: Physical activity carried out during adolescence has no relationship with height, but physical activity carried out during the prepubertal period has a relationship with height.

Keywords: Physical Activity, Height, Students

\section{Pendahuluan}

Prevalensi kejadian tinggi badan pendek atau stunting (masalah kekurangan gizi kronis yang menyebabkan tumbuh tinggi badan anak terhambat) tertinggi di dunia terdapat di Afrika (40\%), dan jumlah terbanyak stunting pada anak dilaporkan terdapat di Asia sebanyak 112 juta. Indonesia memiliki kasus tertinggi dibanding dengan negara lain di Asia Tenggara seperti, Myanmar (35\%), Vietnam (23\%), dan Thailand (16\%). Riset Kesehatan Dasar 2013 menunjukan bahwa sebanyak 14 provinsi di Indonesia termasuk dalam stunting kategori berat, dan sebanyak 15 provinsi termasuk kedalam kategori serius. Terdapat penurunan prevalensi anak dengan tinggi badan pendek di Indonesia dari tahun 2007 (36,8\%) dan 2010 (35,6\%), namun pada tahun 2013 ditemukan peningkatan sebanyak $37,2 \%$ pada anak-anak Indonesia di bawah umur 5 tahun. Masalah kesehatan masyarakat dengan tinggi badan pendek dikategorikan berat apabila didapatkan prevalensi mencapai 30-39\% dan dikategorikan serius bila prevalensi sebesar $\geq 40 \%$ (Dewey \& Begum, 2011; WHO, 2010; RISKESDAS, 2013).

Pertumbuhan ukuran tinggi badan, berat badan dan dimensi tubuh lainnya telah banyak digunakan sebagai indikator kesejahteraan lingkungan dalam penelitian epidemiologi lingkungan dan kesehatan masyarakat. Perbedaan sosial, ekonomi dan politik antara kelompok manusia sering dikaitkan dengan perbedaan rata-rata ukuran tinggi badan dalam suatu kelompok (Bogin et al., 2015).

Pada usia remaja lanjut (usia 18-20 tahun) pertumbuhan tulang-tulang extremitas dapat berhenti memanjang namun, ruas-ruas tulang belakang dapat berlanjut tumbuh kembangnya hingga usia 30 tahun (Soetjiningsih, 2016). Puncak pertumbuhan massa tulang yang optimal dicapai pada awal usia 20 tahun. Dimana, kurangnya pengaruh faktor resiko seperti latihan aktivitas fisik, hormone, asupan kalsium, vitamin D, genetik, dan sebagainya dapat menyebabkan 
pertumbuhan massa (densitas) mineral tulang yang kurang optimal (Desrida et al., 2017).

Faktor lain yang penting sebagai penentu pertumbuhan tinggi badan dan kepadatan tulang. Gen orang tua dan berbagai faktor yang mempengaruhi seperti, asuhan sejak awal kehidupan dalam kandungan, nutrisi, sosio-ekonomi, dan pengaruh luar melalui aktivitas fisik yang juga dapat mempengaruhi tinggi badan (Harahap, Sandjaja, Soekatri, 2015).

Melakukan aktivitas fisik secara berkala dapat meningkatkan kesehatan tulang dan mencegah pengeroposan tulang, Diantara aktivitas fisik yang cukup berpengaruh yakni, sepak bola, renang, dan jalan cepat (Mohr et al., 2015). Kalsium dan vitamin D juga memiliki peran yang essensial dalam pembentukan tulang. Terdapat perbedaan kandungan kalsium dan lemak yang cukup signifikan pada anak tinggi badan pendek dan tinggi badan normal (Stuijvenberg et al., 2015).

\section{Bahan dan Metoda Penelitian}

Jenis penelitian yang digunakan adalah penelitian kuantitatif korelasional yang bertujuan untuk meneliti hubungan aktivitas fisik terhadap tinggi badan pada mahasiswa Fakultas Kedokteran Umum Universitas YARSI dengan usia kurang dari atau sama dengan 20 tahun. Rancangan penelitian yang digunakan adalah penelitian analitik yang dilakukan dengan pendekatan Cross Sectional. Pendekatan Cross Sectional. Pada penelitian ini, populasi yang digunakan adalah mahasiswa Fakultas Kedokteran Universitas YARSI tahun angkatan 2016 \& 2017, berjumlah 106 mahasiswa angkatan 2016 dan 113 mahasiswa angkatan 2017. Penelitian dilaksanakan antara bulan Juni 2018 hingga Juli 2018.
Sampel penelitian merupakan bagian dari populasi yang menjadi responden dengan kriteria inklusi yang pertama adalah Mahasiswa Fakultas Kedokteran Umum Universitas YARSI yang berusia kurang dari 20 tahun, berjenis kelamin laki-laki dan perempuan. Kedua, berstatus sebagai mahasiswa di Universitas YARSI. Ketiga, mahasiswa yang bersedia sebagai responden penelitian yang telah mengisi informed consent yang telah ditandatangani. Kriteria Ekslusi yang pertama adalah mahasiswa tidak masuk perkuliahan pada saat penelitian. Kedua, mahasiswa berumur lebih dari 20 tahun. Ketiga, mahasiswa yang data sampelnya tidak lengkap.

Metode sampling yang digunakan adalah simple random sampling dengan pengambilan sampel yang proporsional pada masing-masing kelas dan menggunakan formula Slovin untuk jumlah sampel minimal. Peneliti akan menganalisa variabel data dengan cara univariat dan bivariat dan dibantu dengan SPSS. Analisa data menggunakan uji pearson chi-square.

\section{Hasil Penelitian}

Dari 219 responden didapatkan mayoritas responden adalah perempuan $(69,4 \%)$, dengan usia termuda sebanyak 17 tahun $(2,3 \%)$, tertua sebanyak 20 tahun $(35,2 \%)$, serta mayoritas responden berusia 19 tahun $(37,4 \%)$ (Tabel 1). Berikut distribusi karakteristik responden dapat dilihat pada Tabel 1. 
Tabel 1. Distribusi Karakteristik Usia, Jenis Kelamin, Tinggi Badan-IMT, Aktivitas Fisik pada Masa Remaja dan Pra-pubertas

\begin{tabular}{lll}
\hline Karakteristik & $\mathbf{f}$ & $\%$ \\
\hline Usia responden & & \\
17 Tahun & 5 & 2.3 \\
18 Tahun & 55 & 25.1 \\
19 Tahun & 82 & 37.4 \\
20 Tahun & 77 & 35.2 \\
Jenis Kelamin & & \\
Laki-laki & 67 & 30.6 \\
Perempuan & 152 & 69.4 \\
Tinggi Badan-IMT & & \\
Pendek-Normal & 19 & 8.68 \\
Pendek-BB Lebih & 4 & 1.83 \\
Pendek-Obesitas & 7 & 3.20 \\
Normal-Kurus & & 17 \\
Normal-Normal & 103 & 47.03 \\
Normal-BB lebih & 23 & 10.50 \\
Normal-Obesitas & 46 & 21.00 \\
Aktivitas Fisik pada Masa Remaja & & \\
low & 16 & 7.31 \\
moderate & 120 & 54.79 \\
high & & \\
Aktivitas Fisik pada Masa Prapubertas & & \\
Kurang Baik & 37 & 16.9 \\
Baik & 7 & 3.2 \\
Sangat Baik & 175 & 79.9 \\
\hline Ketrangan & & \\
\hline
\end{tabular}

Keterangan

$f=$ frekuensi

$\%=$ persentase

\section{Diskusi}

Uji analisa bivariat pada hubungan antara aktivitas fisik yang dilakukan pada masa remaja terhadap tinggi badan menunjukan bahwa tidak terdapat hubungan yang bermakna antara terhadap tinggi badan $(P=0.992>5 \%)$ (Tabel 2).

Tabel 2. Hubungan Aktivitas Fisik terhadap pada masa remaja terhadap Tinggi Badan

\begin{tabular}{lllllllll}
\hline \multirow{2}{*}{\multicolumn{1}{c}{ Tinggi Badan-IMT }} & \multicolumn{9}{c}{ Aktivitas Fisik } & \multicolumn{3}{c}{ Total } \\
\cline { 2 - 8 } & \multicolumn{2}{c}{ Rendah } & \multicolumn{2}{c}{ Sedang } & \multicolumn{3}{c}{ Tinggi } \\
& $\mathrm{f}$ & $\%$ & $\mathrm{f}$ & $\%$ & $\mathrm{f}$ & $\%$ & $\mathrm{f}$ & $\%$ \\
\hline Pendek-Normal & 2 & 12.5 & 8 & 6.7 & 9 & 10.8 & 19 & 8.7 \\
Pendek-BB lebih & 0 & 0.0 & 2 & 1.7 & 2 & 2.4 & 4 & 1.8 \\
Pendek-Obesitas & 0 & 0.0 & 4 & 3.3 & 3 & 3.6 & 7 & 3.2 \\
Normal-Kurus & 0 & 0.0 & 12 & 10.0 & 5 & 6.0 & 17 & 7.8 \\
Normal-Normal & 9 & 56.3 & 58 & 48.3 & 36 & 43.4 & 103 & 47.0 \\
Normal-BB lebih & 2 & 12.5 & 11 & 9.2 & 10 & 12.0 & 23 & 10.5 \\
Normal-Obesitas & 3 & 18.8 & 25 & 20.8 & 18 & 21.7 & 46 & 21.0 \\
\hline Total & 16 & 100 & 120 & 100 & 83 & 100 & 219 & 100 \\
\hline
\end{tabular}

Keterangan

$f=$ frekuensi 
$\%=$ persentase

Hasil penelitian ini berbeda dengan teori beberapa studi yang dikutip dalam (KleinNulend et al., 2015) menyebutkan, olahraga atau aktivitas fisik berintensitas tinggi dapat merangsang regangan (strain) tulang hingga sebanyak 1.000 mikrostrain pada manusia. Selama melakukan aktivitas fisik, kekuatan mekanik akan ditransmisi oleh aktivitas kontraktil otot. Hasil kekuatan fisik ini dapat membantu memelihara massa tulang dan juga menginisiasi pembentukan struktur tulang. Rekonstruksi pada tulang yang dapat dilihat jelas yakni pada tulang trabekular yang ditemukan pada tulang belakang (vertebrae), hal ini akibat gaya mekanis terbesar berpusat pada tulang belakang. Salah satu contoh klasik yang ditemukan dari efek stimulasi rangsangan mekanik pada massa tulang terjadi di lengan bawah atlet tenis, dimana pada os ulna dan jarijari di lengan yang biasa digunakan untuk memegang raket. Pada tulang tersebut akan ditemukan deformasi matriks tulang dan terjadi peningkatan massa tulang $5-10 \%$ dibanding pada tulang tangan sebelahnya yang tidak biasa memegang raket tenis. Deformasi yang terjadi pada tulang terjadi akibat adanya gaya fisik dan mekanis yang disebut juga sebagai regangan (strain), dimana 1.000 mikrostain atau sama dengan $0,01 \%$ menyebabkan perubahan panjang tulang dibandingkan dengan panjang aslinya.

Soetjiningsih (2016) menyatakan bahwa pertumbuhan tulang-tulang ekstremitas (anggota gerak) akan berhenti sekitar usia 1820 tahun, namun ruas-ruas vertebrae (tulang belakang) masih dapat mengalami pertumbuhan hingga usia 30 tahun, dengan pengisian tulang pada ujung atas dan bawah corpus vertebrae (badan tulang belakang), sehingga dapat menyebabkan pertambahan ukuran tinggi badan sekitar 3-5 mm.

Berdasarkan uji Chi-Square pada analisis hubungan aktivitas fisik yang dilakukan semasa pra pubertas terhadap tinggi badan ditemukan, hubungan bermakna $(P=0.045$ $<5 \%$ ) (Tabel 3).

Penelitian cross-sectional oleh Zouch M, et al (2014) pada atlet sepak bola anak-anak periode prapubertas menemukan bahwa mineralisasi tulang dapat dipengaruhi oleh olahraga yang disertai dengan beban mekanis dan daya tahan kekuatan, daripada olahraga yang tidak membutuhkan beban mekanis seperti berenang dan bersepeda.

Tabel 3. Hubungan Aktivitas Fisik Prapubertas terhadap Tinggi Badan

\begin{tabular}{|c|c|c|c|c|c|c|c|c|}
\hline \multirow{3}{*}{ WTinggi Badan-IMT } & \multicolumn{6}{|c|}{ Aktivitas Fisik } & \multirow{2}{*}{\multicolumn{2}{|c|}{ Total }} \\
\hline & \multicolumn{2}{|c|}{ Kurang } & \multicolumn{2}{|c|}{ Baik } & \multicolumn{2}{|c|}{ Sangat Baik } & & \\
\hline & $f$ & $\%$ & $f$ & $\%$ & $f$ & $\%$ & $f$ & $\%$ \\
\hline Pendek-Normal & 4 & 10.5 & 0 & 0.0 & 15 & 8.5 & 19 & 8.7 \\
\hline Pendek-BB Lebih & 0 & 0.0 & 1 & 20.0 & 3 & 1.7 & 4 & 1.8 \\
\hline Pendek-Obesitas & 4 & 10.5 & 0 & 0.0 & 3 & 1.7 & 7 & 3.2 \\
\hline Normal-Kurus & 2 & 5.3 & 0 & 0.0 & 15 & 8.5 & 17 & 7.8 \\
\hline Normal-Normal & 16 & 42.1 & 3 & 60.0 & 84 & 47.7 & 103 & 47.0 \\
\hline Normal-BB Lebih & 5 & 13.2 & 1 & 20.0 & 17 & 9.7 & 23 & 10.5 \\
\hline Normal-Obesitas & 7 & 18.4 & 0 & 0.0 & 39 & 22.2 & 46 & 21.0 \\
\hline Total & 38 & 100 & 5 & 100 & 176 & 100 & 219 & 100 \\
\hline $\begin{array}{l}\text { Keterangan } \\
\mathrm{f}=\text { frekuensi } \\
\%=\text { persentas }\end{array}$ & & & & & & & & \\
\hline
\end{tabular}


Dalam penelitian Larsen et al., (2017) melaporkan bahwa Bone Mineral Content (BMC) dan Bone Mineral Density (BMD) pada tungkai bawah pemain atlet sepak bola memiliki kadar yang lebih tinggi dibandingkan dengan pemain klub yang tidak aktif, sehingga disimpulkan bahwa mineralisasi tulang mungkin dipengaruhi oleh latihan fisik berdurasi lama dan jangka waktu latihan fisik yang biasa dilakukan.

Melakukan aktivitas fisik mulai dari anak usia dini terutama disertai penambahan beban mekanis dapat meningkatkan enzim tulang, pembesaran tulang (bone hypertrophy), dan kekuatan tulang yang optimal pada masa remaja. Seperti halnya otot, tulang harus dilatih secara fisik guna merangsang pembentukan tulang baru dan memperkuat tulang. Aktivitas fisik dengan penambahan beban mekanis ditemukan lebih efektif daripada yang tanpa beban seperti misalnya, berenang, bersepeda, melompat, dan berlari (Desrida, Afriwardi, Kadri, 2017).

\section{Simpulan}

Penelitian ini menemukan bahwa terdapat hubungan yang signifikan pada pengaruh aktivitas fisik pada masa prapubertas terhadap tinggi badan, namun tidak mendapatkan hubungan yang signifikan antara aktivitas fisik pada masa remaja terhadap tinggi badan responden.

\section{Saran}

Penelitian ini perlu dilanjuti secara longitudinal sehingga memudahkan peneliti selanjutnya dalam menentukan variabel mana yang terjadi lebih dahulu, selain itu penambahan hubungan faktor resiko lain yang dapat berpengaruh pada ukuran tinggi badan responden seperti kadar kalsium dalam darah, asupan nutrisi dan kalsium, panjang bayi saat lahir, faktor sosial-ekonomi dan faktor lainnya.

\section{Ucapan Terimakasih}

Terimakasih kepada Universitas YARSI dan Program Studi Kedokteran Umum yang memberikan kesempatan untuk mempublikasikan skripsi ini.

\section{Daftar Pustaka}

Bogin et al., 2015, 'Sex, Sport, IGF-1 and the Community Effect in Height Hypothesis', International Journal of Environmental Research and Public Health, 12, 48174822.

Desrida, Afriwardi, Kadri H. 2017. 'Hubungan Tingkat Aktivitas Fisik, Jumlah Asupan Vitamin D dan Kalsium Terhadap Tingkat Densitas Tulang Remaja Putri di SMA Negeri Kecamatan Tilatang Kamang Kabupaten Agam', Jurnal Kesehatan Andalas, 6(3), 572-580.

Dhewey KG dan Begum K. 2011. 'Long-term Consequences of Stunting in Early Life', Blackwell Publishing Ltd Maternal and Child Nutrition, vol. 7 (Suppl. 3), 5-18.

Harahap H, Sandjaja, Soekatri M. 2015, "Kepadatan Tulang, Aktivitas Fisik, dan Konsumsi Makanan Berhubungan dengan Kejadian Stunting pada Anak Usia 6-12 Tahun". Gizi Indon 2015, 38 (1), hh:1-8.

Klein-Nulend $J$, van Oers RF, Bakker $A D$ \& Bacabac RG. 2015. Bone cell mechanosensitivity, estrogen deficiency, and osteoporosis. Journal of Biomechanics, 48(5), 855-865.

Mohr et al., 2015. 'Effects of Soccer vs Swim Training on Bone Formation in Sedentary 
Middle-Aged Women', European Journal Applied of Physiology, vol.115, 26712679.

Riset Kesehatan Dasar. 2013. Jakarta: Badan Penelitian dan Pengembangan Kesehatan Kementrian Kesehatan RI.

Soetjiningsih. 2016, "Tumbuh Kembang Anak", Jakarta: EGC

Stuijvenberg et al., 2015, 'Low intake of calcium and vitamin $D$, but not zinc, iron or vitamin $A$, is associated with stunting in 2- to 5year-old children'. Nutrition Journal, 31 , 841-846.
World Health Orgnization. 2010, Global Health Recommendations on Physical Activity for Health, Geneva: WHO Library Cataloguing-in-Publication Data, http://www.who.int/dietphysicalactivity/fact sheet_recommendations/en/, diakses pada 25 may 2018.

Zouch M, Vico L, Frere D, Tabka Z \& Alexandre C. 2014. Young male soccer players exhibit additional bone mineral acquisition during the peripubertal period: 1-year longitudinal study. Eur J Pediatr, 173(1), 53-61. 